Scholarship Repository

University of Minnesota Law School

Articles

Faculty Scholarship

2019

\title{
Ameliorating the Federal Trial Penalty through a Systematic Judicial "Second Look" Procedure
}

JaneAnne Murray

University of Minnesota Law School, murrayj@umn.edu

Follow this and additional works at: https://scholarship.law.umn.edu/faculty_articles

Part of the Law Commons

\section{Recommended Citation}

JaneAnne Murray, Ameliorating the Federal Trial Penalty through a Systematic Judicial "Second Look" Procedure, 31 FED. SENTENCING R. 279 (2019), available at https://scholarship.law.umn.edu/ faculty_articles/648.

This Article is brought to you for free and open access by the University of Minnesota Law School. It has been accepted for inclusion in the Faculty Scholarship collection by an authorized administrator of the Scholarship Repository. For more information, please contact lenzx009@umn.edu. 


\section{Ameliorating the Federal Trial Penalty through a Systematic Judicial "Second Look" Procedure}

We can't lose sight of the fact that when you imprison somebody for ten years, fifteen years, twenty years, there's a human toll that should not be ignored in the process. And in fact when you put somebody in jail for that length of time, you take away all hope. And out of that a great despair arises.

-Judge Theodore McKee, U.S. Circuit Court Judge

The sentencing judge is the person who commits prison beds, determining who goes to prison and for how long. - Senator Edward M. Kennedy ${ }^{2}$

Defendants in our criminal justice system today face widely divergent choices in almost every case. Although they enjoy the most rights the law extends to any parties appearing before a court, the trial penalty - the threat of a substantially more severe conviction or longer sentence after trial than the one available upon a guilty plea-almost always renders these protections academic.

As it erases substantive due process protections for criminal defendants, the trial penalty becomes a key driver of mass incarceration. Not only does it propel defendants to accept guilty pleas early in the process (thus freeing prosecutors to focus resources on more cases), it is often operationalized in disproportionately long custodial sentences-sometimes extremely long sentences. Whether imposed after a rare exercise of the right to trial or, more commonly, as a result of a plea bargain in the shadow of a much more severe outcome, these long "trial penalty sentences" have become the mainstay of U.S. mass incarceration.

There is no data on how many federal inmates are serving sentences driven by a penalty that represents an unduly punitive response to a guilty verdict after trial or that effectively neutered the defendant's consent in the plea process. And it is important to emphasize that not all long sentences are driven by the trial penalty. Some would have been imposed regardless of how guilt was adjudicated. Some represent a plea discount-a modest reduction of the sentence that would have been imposed had there been a trial. And some represent a plea windfalla sentence significantly lower than the charged facts would justify.

But there is a realization, exemplified in recent statutory and guideline changes, as well as President Barack
Obama's clemency initiative, that there are thousands of federal inmates serving unnecessarily harsh sentences imposed at a "retail" level after trial or extracted through onerous plea bargains. To get a sense of the potential numbers, of the 180,000 or so current federal inmates, almost 50 percent are serving sentences of io years or more, and almost 30 percent are serving sentences of I5 $_{5}$ years or more, ${ }^{3}$ and unlike the state prison inmate composition, almost half the federal inmate population is incarcerated on drug charges. ${ }^{4}$

In a September 2017 report, the U.S. Sentencing Commission estimated that at the end of President Obama's presidency, approximately 2,600 federal inmates-who had been incarcerated at the time the initiative was announced and were still behind bars without a grant of clemency when he departedappeared to have met the extremely high bar of the announced factors for his clemency initiative: low-level, non-violent offenders, with no ties to gangs or cartels, with Io years served and a good prison record, and whose sentences would be lower today by operation of law or policy. ${ }^{5}$ To those familiar with the cases of federal inmates, this 2,600 figure represents the proverbial tip of the iceberg of those deserving a sentence modification.

Moreover, behind these statistics of long sentences are well-documented and deeply troubling racial disparities. ${ }^{6}$ Even more disturbing, a large number of inmates are serving sentences that would not be imposed today. Some sentences were meted out prior to the Supreme Court's decision in Booker (which rendered the then-mandatory sentencing guidelines advisory) or prior to any subsequent Supreme Court cases that flesh out Booker's deference to proportionality and individuation. Some sentences represent draconian uses of mandatory minimum penalties recently reduced by the First Step Act, but which were not made retroactive. Some sentences represent charging and sentencing priorities that have undergone a sea-change in recent years as prosecutors, guidelines experts, and judges absorb the human toll and scientific insights that reveal just how unduly severe and ineffective these sentences turned out to be.

This essay focuses on one proposed mechanism for ameliorating the excessive sentences produced by the trial penalty: the post-sentencing judicial "second look" at the

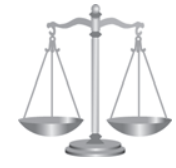

\section{JANEANNE} MURRAY*

Professor of

Practice, University of Minnesota Law School

Practicing Federal Criminal Defense Attorney

Federal Sentencing Reporter, Vol. 3I, No. 4 \& 5, pp. 279-283, ISSN 1053-9867, electronic ISSN 1533-8363. (C) 20I9 Vera Institute of Justice. All rights reserved. Please direct requests for permission to photocopy or reproduce article content through the University of California Press's Reprints and Permissions web page, https://www.ucpress.edu/journals/reprints-permissions. DOI: https://doi.org/IO.I525/fsr.20I9.3I.4-5.279. 
propriety of a particular sentence after the offender has served a substantial period in prison. Most particularly, it sketches out what that process could look like at the federal level, and examines a leading objection to adopting it: that it is economically prohibitive and would over-burden the federal court system.

\section{The Role of the Trial Penalty in Producing Disproportionately Long Sentences}

Almost eleven million people revolve through the doors of our jails and prisons each year, which incarcerate about 2.2 million people at any given moment. But the truly devastating and human toll in the "mass" component of our mass incarceration is in the actual years that people face and serve. This is true nationally, but especially so at the federal level, as noted above, with its high proportion of long sentences. The analysis of the federal inmate landscape becomes even more troubling when we consider how many are drug defendants (almost 50 percent) and the fact that these are disproportionately concentrated among the poor, people of color, and those who are mentally ill. ${ }^{7}$

The National Association of Criminal Defense Lawyers' Trial Penalty Report (the Report) rightly focuses on the trial penalty- the gap between the sentence on a guilty plea and the likely sentence after trial—as a crucial component of a criminal justice system characterized by harsh sentences. As the Report demonstrates, the sentence after trial in federal cases is at least double the sentence imposed in cases where the defendant pled guilty, and as practitioners know, in cases involving mandatory minimum sentences, recidivist enhancements, or oncemandatory guidelines, the post-trial sentence can be much longer.

Consider the case of Derrin Perkins. Arrested by local police in I99I, unarmed, in possession of only I7 grams of crack cocaine, he was prosecuted first locally and later federally for drug distribution by prosecutors seeking his testimony in a street-level crack distribution scheme run in Perkins' neighborhood by his childhood friends. A plea offer of five years was extended to Perkins and several of his codefendants as long as they all agreed to cooperate against others. The collective plea bargaining effort failed, and at 26 years of age, Perkins went to trial and was convicted. His guideline sentence, based on the quantity of drugs distributed by the larger conspiracy of which he was merely a lowly player, was mandatory life. ${ }^{8}$ There was no allegation that he ever personally carried a weapon or acted violently. He was sentenced to life in prison.

But even though Perkins' case represents a stark illustration, the trial penalty ironically has a greater impact in the 97 percent of adjudicated cases that do not end in an actual trial, including the cases with unusually long sentences. Again, using an actual case, Raeanna Paxton, a mother of five, was an unarmed driver for a minor dealer "in a situation where methamphetamine-addicted individuals resorted to selling the drug to support their own addictions." 9 Prosecutors threatened her with a mandatory life sentence based on her two minor prior drug convictions, for which she had served little or no jail time, unless she accepted a stipulated sentence of between 2I to 27 years. Faced with spending the rest of her life behind bars, Ms. Paxton had no choice but to accept that plea offer, and the judge had no choice but to sentence her to the 2I-year minimum. ${ }^{\text {Io }}$

Experiences like those of Perkins and Paxton proliferate throughout the criminal justice system. Researchers are finally appropriately focusing on prosecutors and their charging practices as a causal factor in not only the volume of prison inmates but also the length of the sentences they face. Changes are afoot at the pre-sentencing ground level, through prosecutorial policies and statutory and guideline amendments. But what is to be done about the individuals currently serving lengthy sentences in prison, whose meager review rights dwindle to extinction as their years behind bars mount?

\section{A Systematic Federal Judicial "Second Look" at Sentences}

Acknowledging America's exceptional and exponential use of lengthy prison terms over the last 40 years, and the necessity for restraint in imposing sentences that stretch through a generation, the drafters of the revised Model Penal Code (MPC) of the American Law Institute have included a unique, and ambitious "second look" procedure for prisoners serving long sentences. ${ }^{\text {II }}$ The proposal, couched as a "principle for legislation," would permit an inmate to apply to a judicial panel or a judicial decision maker for a sentencing modification after having served a substantial portion of their prison term and, if unsuccessful in the initial application for a sentencing reduction, at intervals thereafter. It includes provisions for the appointment of counsel and for appellate review, as well as for victim participation in the resentencing.

This section uses the MPC's "second look" template to sketch how that process could work in the federal context. It adopts, for the most part, the main features of the MPC's proposal, with specific recommendations for particular alternatives proposed by the MPC in light of the current make-up of the federal inmate population and the lessons we have learned from recent resentencing programs (based on retroactive statutory and guideline changes, as well as President Obama's clemency initiative).

I. A "Second Look" After ro Years in Non-Violent Cases, I5 in Violent Cases. The MPC proposes I5 served years as the point at which a "second look" at the original sentence is authorized (cognizant of the impact on already overburdened state court systems if it set a shorter time period). The MPC, thus, presumes its "second look" provision focuses on those who have committed "the most serious offenses and victimizations." ${ }^{22}$ I propose that a federal "second look" program set a shorter term for non-violent offenses. Unlike the state system, almost half 
the offenders in the federal system are drug offenders, and as President Obama's clemency initiative demonstrated, many are serving sentences that are significantly disproportionate to their actual conduct due mainly to prosecutors' over-use of lengthy mandatory minimum sentences and sentencing guidelines improperly pegged to penalties intended for king-pins. A "second look" provision after Io years permits an opportunity to reconsider these long sentences in light of new evidence-based policies, provides hope to the offenders serving them, and incentivizes and rewards the profound turn-around that many of these offenders display after years of substance abuse and untreated mental illness.

2. Unconstrained by Mandatory Minimum Penalties. To ensure that the sentence-modification authority is meaningful, it is critical, as proposed by the MPC, that the enabling legislation permit judges to resentence below any applicable mandatory-minimum penalties. ${ }^{\mathrm{I} 3}$ This relief is consistent with research that links mandatory minimum sentencing statutes to the shift of sentencing power to prosecutors and to the rise in prison populations. ${ }^{\text {I4 }}$ It also reflects the changing public attitudes to inflexible mandatory minimum sentences. ${ }^{15}$

3. Before the Original Sentencing Judge, Advised by a Panel of Federal District Judges. The MPC squarely places the sentencing reconsideration authority in the judicial sphere, recommending that it be exercised by a judge or "a judicial panel or other judicial decisionmaker." ${ }^{\text {"6 }}$ I propose a panel of district judges, with one judge (the original sentencing judge, if available) making the final decision and imposing the new sentence. Brooklyn Judge Jack Weinstein described in United States v. Butler how, after Booker, his district had reinstituted the practice of convening sentencing panels to advise the sentencing judge, quoting sentencing scholar Daniel J. Freed's admonition to judges "to reason among themselves" about sentencing. ${ }^{\text {I7 }}$ An advisory panel has several advantages. For example, it carries the potential to moderate extreme views, pools and promotes the development of expertise, distributes responsibility over more than one individual, and helps reduce disparities in the resentencing process. District courts could experiment with the make-up of these advisory panels, choosing, instead of judges, stakeholders from different constituencies, including crime victims and former offenders.

4. Substantive Resentencing. As proposed by the MPC, the federal sentence modification procedure should be a resentencing based on current circumstances. The inquiry, as the MPC sums up, is "whether, in light of current information, the purposes of sentencing ... would best be served by completion of the original sentence or a modified sentence." ${ }^{18}$ Obviously, this would include an analysis of the circumstances of the offense of conviction and all relevant aggravating and mitigating factors, but it would also consider the inmate's prison record, scientific developments in the understanding of offender rehabilitation and risk assessment, and society's evolving views about criminal policy and sentencing. The U.S. Sentencing Commission could be tasked with establishing eligibility criteria and guidelines to ensure uniformity in decision making. In addition, provisions could be made for this process to occur without a formal hearing (as happened in thousands of the cases involving retroactive adjustments in recent years).

5. Appointment of Counsel. With de novo sentencing, it is critical that an eligible inmate has counsel. Someone who has spent over a decade in prison is ill-suited to craft their own resentencing position, particularly given the kind of sophisticated analysis necessary to address changed sentencing practices and policies. Because many cases involving sentence modification may be decided on paper filings alone, it makes sense to adopt the practice used in most districts in the context of the retroactive application of Amendment 782, and appoint the local federal defender to represent all potentially eligible inmates. These federal defenders could, in turn, assign cases to one of the 3,700 assistant federal defenders or one of the 12,000 private "panel" attorneys who accept assignments under the Criminal Justice Act. ${ }^{19}$

6. Right to Appeal. As with motions for retroactive adjustments under the Sentencing Guidelines, inmates should have a right to appeal the outcome of their sentence modification motion under a reasonableness standard.

\section{The Costs of a Judicial "Second Look" Procedure in the Federal System}

One of the main critiques of a judicial "second look" sentencing procedure is the inevitable burden on the court system and related re-entry and supervision services. These concerns are real, given the emphasis on long sentences in our federal system.

What precisely would be the caseload impact of a sentence-modification procedure on an annual basis at the federal level? Although just about half of our current federal prisoners are serving sentences of Io years or more and about one-third are serving sentences of 15 years or more, I could locate no data on how many have actually served ro years, such that they would be immediately eligible to apply for a "second look." ${ }^{20}$ It would doubtless be a substantial number, easily in the region of Io percent of the current population. Thereafter, one could assume that an additional several thousand inmates would become eligible each year.

Needless to say, this would result in a significant initial increase in court dockets. In addition, the increase would not be evenly distributed among the 650 or so federal district judges, since some districts produce more long sentences than others. ${ }^{2 \mathrm{I}}$ If this process were to benefit I8,000 inmates in its first year (Io percent of the current population), that works out, on average, at 28 individual resentencings per district court judge (and if we factor in sentencing panels, this means an additional 50 or so sentencing recommendations per judge). Can our system handle the magnitude of this endeavor, logistically and 
financially? Recent related experiences indicate that it can-as long as the undertaking is accompanied by the employment of additional personnel, quality technological assistance, and dedicated participants across groups of stakeholders (judges, prosecutors, probation officers, and defense lawyers).

First, regarding the financial cost, given the high number of federal drug inmates serving long sentences, the "second look" procedure will likely result in reduced sentences for a large number of inmates, perhaps thousands. The savings on the costs of custody will be considerable. The Sentencing Commission estimates that Amendment 782, which retroactively lowered the sentences of drug offenders, reduced the sentences of 3I,000 inmates, with an average reduction of 25 months. ${ }^{22}$ Assuming an annual cost of $\$ 29,000$ to house an inmate, ${ }^{23}$ this resulted in savings of almost $\$ 2$ billion. A "second look" program would likely produce similar savings. Some of these savings could be diverted to fund the measure's impact on resources.

Second, the federal court system's experience implementing Amendment 782, as well as other retroactive sentencing measures, illustrates its capacity to handle the administrative challenges of resentencing on a large scale. District courts reviewed 48, OI3 cases under Amendment 782 , granting reduced sentences in just over 3I,000. ${ }^{24}$ Supreme Court Fellow Caryn Devins has conducted a rich empirical study of the 782 implementation process, finding that stakeholders reported it was "for the most part, smooth and orderly," with judges often working with "probation officers and representatives from the U.S. Attorney's Office and federal defender organizations in order to create expedited sentencing processes." ${ }^{25}$ Judges usually granted the available sentence reduction in full to eligible individuals, often on their own motions without input from any parties. A "second look" program, by contrast, since it involves substantive resentencing and the potential for far bigger reductions, will be far more involved and time-consuming for all concerned. Nonetheless, the 782 process reveals the potential for systematizing, and to the extent possible, streamlining the administration of a "second look" program. One could envisage, for example, collaborative panels of stakeholders making unanimous sentence-reduction recommendations for individuals scoring high on a set of "second look" guidelines, thus freeing time and resources to address contested determinations.

Finally, the experience under President Obama's clemency program, which lasted approximately 2.5 years, also illustrates the capacity of a relatively small number of stakeholders in our criminal justice system to prepare, review, and analyze the cases of large numbers of applicants for sentence reductions. As the Office of the Inspector General reported, the Department of Justice (DOJ) made recommendations to the White House on over 13,000 petitions, resulting in I,696 inmates receiving clemency. The primary review work was conducted by the relatively skeletal staff at the Office of the Pardon Attorney (OPA), which consisted of 22 staff, supplemented by volunteer part-time lawyers from other DOJ units and io full-time lawyers detailed to the OPA in April 20I6. ${ }^{26}$ On the defense side, NACDL reported that Clemency Project 20I4, the volunteer effort by a consortium of defense organizations, succeeded in screening 36,000 inmates for clemency eligibility and recruiting and training 4,000 volunteers, ultimately submitting almost 2,600 individual clemency petitions, each of which had been reviewed both by panels of screening attorneys and by the entire Io-member steering committee-all on a pro bono basis. ${ }^{27}$

In sum, a "second look" program would be a significant undertaking, but it is affordable based on the savings from incarceration costs, and one the federal court system has the demonstrated capacity to implement systematically.

\section{Conclusion}

Judge Jack Weinstein once said that sentencing is the moment that most clearly reveals the human face of the law. ${ }^{28}$ When the sentence stretches into decades, as it did for Derrin Perkins and Raeanna Paxton, the law's face can be sorely lacking in humanity. It is also, as the MPC maintains, lacking in humility: "It would be an error of arrogance and ahistoricism to believe that the criminal codes and sentencing laws of our era have been perfected to reflect only timeless values." ${ }^{29}$ These laws empowered prosecutors to secure lengthy sentences post-trial or through plea bargains struck in the shadow of the trial penalty. A systematic judicial "second look" procedure would restore some decency and reason to a sentencing system that has consigned too many people to prison for far too long.

\section{Notes}

* The author can be reached at murrayj@umn.edu. She wishes to thank Howard Lavine, Michael Murray, Norman Reimer, and Martín Sabelli.

1 See Margaret Colgate Love, Sentence Reduction Mechanisms in a Determinate Sentencing System: Report of the Second Look Roundtable, 21 Fed. Sent'g Rep. 211, 219 (2009).

2 Edward M. Kennedy, Prison Overcrowding: The Law's Dilemma, 478 Ann. Am. Acad. Pol. \& Soc. Sci. 113, 118 (Mar. 1985) (laying out the reasoning behind the Sentencing Reform Act of which he was the chief sponsor).

3 See Federal Bureau of Prisons, Sentences Imposed (Mar. 23, 2019), https://www.bop.gov/about/statistics/statistics_ inmate_sentences.jsp.

4 See Federal Bureau of Prisons, Offenses (Mar. 23, 2019), https://www.bop.gov/about/statistics/statistics_inmate_ offenses.jsp.

$5 \quad$ U.S. Sentencing Commission, An Analysis of the Implementation of the 2014 Clemency Initiative (Sept. 2017) at 2, https://www.ussc.gov/sites/default/files/pdf/research-andpublications/research-publications/2017/20170901_ clemency.pdf.

6 See, e.g., U.S. Sentencing Commission, Demographic Differences in Sentencing (Nov. 2017) at 3, https://www.ussc.gov/ sites/default/files/pdf/research-and-publications/researchpublications/2017/20171114_Demographics.pdf; Nat'l Research Council, The Growth of Incarceration in the United States: Exploring Causes and Consequences 91-101 (Jeremy traces et al. eds. 2014) ("Growth of Incarceration"). 

https://www.bop.gov/about/statistics/statistics_inmate_ race.jsp; Christie Thompson \& Taylor Elizabeth Eldridge, Treatment Denied: The Mental Health Crisis in Federal Prisons, the Marshall Project (Nov. 21, 2018), https://www. themarshallproject.org/2018/11/21/treatment-denied-the mental-health-crisis-in-federal-prisons.

8 The facts of Perkins' case are set forth in full in the D.C. Circuit decision affirming his conviction. See United States v. Thomas, 114 F.3d 228 (D.C. Cir. 1997); see also Dan Hellman, Prof. Murray, King \& Spalding Score Major Victory in Pro Bono Clem. ency Work (July 16, 2018), https://www.law.umn.edu/news/ 2018-07-16-prof-murray-king-spalding-score-major-victorypro-bono-clemency-work.

9 See Michael Kranish, As U.S. Attorney, Whitaker Imposed Longer Than Usual Drug Sentences, Wash. Post, Nov. 21, 2018, available at https://www.washingtonpost.com/politics/as-usattorney-whitaker-imposed-longer-than-usual-drugsentences/2018/11/21/a66dfaf2-e9de-11e8-bbdb $10 \quad 1 d$

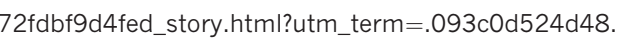

American Law Institute, Model Penal Code: Sentencing, Proposed Final Draft (April 10, 2017; approved May 17, 2017) (Kevin R. Reitz, Reporter, \& Cecelia Klingele, Asso. ciate Reporter) at 568 [hereinafter MPC], available at https://robinainstitute.umn.edu/publications/model. penal-code-sentencing-proposed-final-draft-approved. may-2017

12 ld. at 569.

13 Id. at 578.

14 Growth of Incarceration, at 101-03.

15 See Loren Siegel, A New Sensibility: an Analysis of Public Opin. ion Research on Attitudes Towards Crime and Criminal Justice Policy 16-20 (The Opportunity Agenda, June 2016) (collating data from over 50 opinion surveys).
Notably, a large portion of the 10. to 15-year cohort might never be eligible for a sentence modification, with the application of good-time credits, reductions for participation in the prison's residential drug treatment program, and new release opportunities under the First Step Act.

21 See Federal Bureau of Prisons, Inmate Race, supra note 6.

22 See U.S. Sentencing Commission, 2014 Drug Guidelines Amendment Retroactivity Data Report at tbl. 7 (Jan. 2018) [hereinafter USSC, 2014 Report], available at https://www. ussc.gov/sites/default/files/pdf/research-and-publications/ retroactivity-analyses/drug-guidelines-amendment/ 20180201-Drug-Retro-Analysis.pdf.

23 See Bureau of Prisons, Federal Prison System Per Capita Costs, FY 2015, available at https://www.bop.gov/foia/fy15_ per_capita_costs.pdf. See USSC, 2014 Report, supra note 20, at tbl. 1.

25 See Caryn Davis, Lessons Learned from Retroactivity Resentencing after Johnson and Amendment 782, 10 Fed. Cts. L. Rev. 39, 71, 74 (2018)

26 See Office of the Inspector General, Review of the Depart ment's Clemency Initiative at 15, 41 (Aug. 2018), available at https://oig.justice.gov/reports/2018/e1804.pdf.

27 See Press Release, National Association of Criminal Defense Lawyers \& Foundation for Criminal Justice Applaud the Clemency Project 2014 (Jan. 19, 2017), https://www.nacdl. org/NewsReleases.aspx?id=45111.

28 Jack B. Weinstein, The Role of Judges in a Government Of, By and For the People: Notes for the 58th Cardozo Lecture, 30 Cardozo L. Rev. 1, 178 (2008).

29 MPC, supra note 9 , at 570. 